\title{
THE ROLE OF IgM-ENRICHED INTRAVENOUS IMMUNOGLOBULIN IN TRANSPLANTATION
}

\author{
Szabó Judit, Smudla Anikó, Fazakas János \\ Semmelweis University, Department of Transplantation and Surgery, Hungary
}

Primljen/Received 24. 02. 2014. god.

\begin{abstract}
After organ transplantation, gamma globulin and intravenous immunoglobulin enriched with IgM are most frequently used in septic shock as early immune-support. If the explanted organ is infected, the transplantation, as a life-saving operation, can be performed if there is no systemic inflammation and the patient receives IgM enriched immunoglobulin prophylaxis during surgery. The period after transplantation can be divided into three parts from the infection point of view: the first month after transplantation, the first sixth months and the following six months. Infections within the first month are basically related to the surgical procedure. Because of the immunosuppressive therapy, the opportunistic and fungal infections are more common during the first sixth months. After this period, the occurrence and the type of infections are similar to that of the non-transplant population except for pulmonary infections. The latter is two to three times more frequent. This is explained by the secondary hypogammaglobulinaemia (lower blood levels of IgM and IgG) which is caused by the steroids but most of mycophenolate mofetil by inhibition of the $\mathrm{T}$ and $\mathrm{B}$ lymphocyte proliferation. Septic shock develops with a continuing fall of IgM levels. Under these circumstances additional intravenous immunoglobulin therapy with $\operatorname{IgM}$ can be lifesaving. Besides, immunoglobulin concentrates with IgM may also be used in the case of viral infections without prophylaxis and/or without etiological therapy such as in the case of West Nile virus infection. As a result of the increase in antibiotic resistance, the application of immunotherapy, including immunoglobulins may become the mainstream in the treatment of septic shock.
\end{abstract}

Key words: immunoglobulin, IgM, septic shock, transplantation.

\section{INTRODUCTION}

The immunoglobulin therapy started more than 100 years ago with the use of anti-diphtheria serum
Prihvaćen/Accepted 24. 03. 2014. god.

from horse and continued with the successful treatment of primary and secondary immunodeficiency with intravenous immunoglobulin (IVIG) products. Later on, this was augmented by the use of gamma globulin in the treatment of Guillan Barré syndrome, Kawasaki disease, chronic demyelinating polyneuropathy and different autoimmune diseases. Currently, the use of IVIG is integrating evidence-based practice in this field (1). The use of immunoglobulin in severe sepsis, septic shock is controversial $(2,3,4)$, but a recent Cochrane analysis from 2013 highlighted the favorable effects of early treatment (5) (Table 1).

Monserrat et al. proved that the B lymphocytes reduced CD23 and elevated CD80 production in septic patients, which may result in high mortality rates (6). Moreover, the altered rate of immunoglobulin production also showed effects on outcome in sepsis: IgG1,

Table 1. Effects of intravenous immunoglobulin

\section{Neutralisation of toxins}

- Endotoxin, exotoxin, Gram negative bacterium: molecular patterns

- Reception of endotoxin by the liver and the spleen

- Decreases the bacterium's adherence to other organs

Leukocyte stimulation and increased bactericide effect

- Neutrophil: increased phagocytosis

- Increased opsonization

- Increased oxidative bactericide effect on

T lymphocyte

- Kuppfer cell increased phagocytosis

Inflammatory cytokine effect regulation

- decrease of pro-inflammatory cytokine

- Increase of anti- inflammatory cytokine

Complement effect modulation

- C4, C3 effect reduction through leukocyte 
total IgG, IgM and IgA have an independent protective role in severe sepsis and septic shock $(7,8)$.

During the last decade, the number of nosocomial infections caused by multiresistant pathogens increased significantly and further increase is expected. The development of antibiotics can only hardly or not at all keep up with the change of resistance, thus sooner or later the need for the wider use of immunoglobulins may become a reality $(9,10)$. It is important to note, that the guidelines in 2013 also recommend IVIG for the therapy resistant or severe Clostridium difficile infections (11).

In the field of transplantation, immunoglobulins are also used for the treatment of immunological diseases with infectious or non-infectious causes. One option for the treatment of non-infectious diseases is the therapy of antibody-mediated rejections or for example desensibilisation (12). The other option is the adjuvant treatment of transplanted patients, which is usually performed with the use of gamma globulin or intravenous immunoglobulin enriched with IgM. The early use of immunoglobulins in septic shock in transplanted patients is logical because of the immunosuppression (Figure 1).

\section{INFECTIONS DURING TRANSPLANTATION}

Immunosuppression of the recipient can clearly be verified before transplantation based on the major, minor and laboratory criteria of immunodeficiency (13). Infections during transplantation occur because of the immunodeficient state due to the end-stage organ failure and the transitory ceasing of the barrier functions protecting the integrity of the body during the surgical procedure. Kidney failure and its treatment correlates with the reduced function of specific and non-specific protecting mechanisms. In case of peritoneal or hemodialysis the insufficiency of the non-specific protecting mechanisms may develop. The impairment of the specific protecting components occurs during the contact with the dialysis membrane (loss of complements, leukocyte dysfunction, IgG and IgM reduction due to the increased loss of proteins), but the reduction of the cellular immunity is due to the direct effects of uremia (14). Acute liver-failure as well as end-stage cirrhosis also implies immunodeficiency. The immunological role of the liver as we know is extremely important: the Kuppfer cells of the liver eliminate endogen bacteria from the portal vein, the liver synthetizes $90 \%$ of the complement cascade and the liver eliminates the extrahepatically opsonized bacteria. In liver-failure both the production of complements which take part in the opsonization, and the elimina-

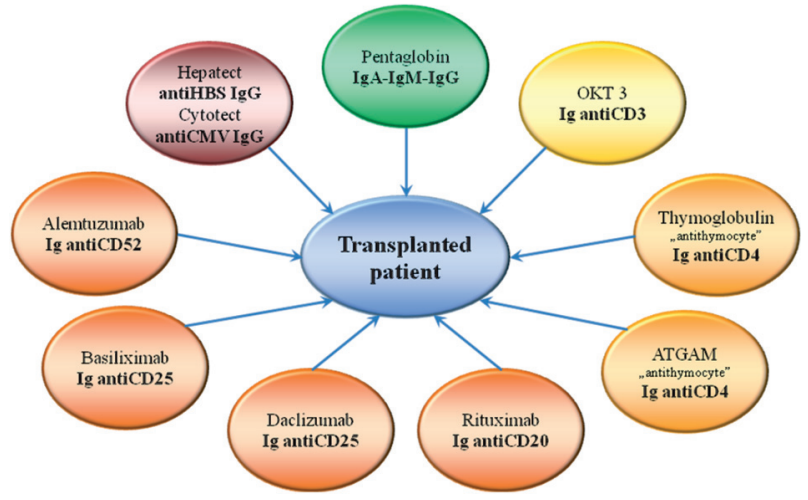

\section{Figure 1. Immunoglobulin products used with transplanted patients}

tion of the opsonized organisms are severely impaired. In $80 \%$ of patient suffering from end-stage liver failure severe infections can be found, and in quarter of these patients have detectable bacteremia. The bacterial invasion's primary places of occurrence are the respiratory, urinary and peritoneal space.

In case of the intestinal flora-originated bacteremia (Escherichia coli, Klebsiella) the bacteria get through to the peritoneal space, where in the presence of ascites spontaneous bacterial peritonitis (SBP) can develop. The diagnosis is based on the increased number of leukocytes in the ascites (in ascites $>250$ cell/ $\mu \mathrm{l}$ ) or the direct detection of the pathogen from the ascites (15).

The relationship between end-stage heart and lung disease and infection is a long known fact. There is weaker protection due to impaired circulation and oxygenation, which results in the disorder of the natural, not specific immunity which provides weaker protection against aerobic and anaerobic pathogens.

Infection occuring during the operation is caused by the breakthrough of bacteria through barriers protecting the body's integrity. The translocation is also helped by the transitory changes in the perfusion and oxygenation during the operation (14). Furthermore, there is a possibility of the donor organ carrying infection. When the focus of the infection is localized in the organ waiting to be removed and there is no systemic inflammation, hence the focus is inactive, under well-defined circumstances the transplantation as a live-saving operation can be performed. In this case the IgM-enriched immunoglobulin prophylactic therapy is recommended only during the time of the surgical procedure. A typical example is the cholangitis in patients suffering from ulcerative colitis causing cirrhosis and sometimes occurring with abscesses, or the primer biliary cirrhosis where in the recipients in the portal triads fragments of translocated bacteria and $\operatorname{IgM}$ can be identified together (16). Prior to transplantation the acute infection must be ruled out. In the literature there are case studies indicating that in certain cases it is pos- 
sible to go astray from the guidelines. For example in a patient suffering from acute bacterial infection the transplantation can be performed, but it can only be done under the protection of IgM-enriched immunoglobulin. In addition the infection can be completely obliterated until the 5th postoperative day or until when the combined immunosuppression is being built up $(7,17)$. There are Hungarian experiences as well in this field. We recently treated a 30 year old mother of three children, whose antibiotic treatment for a right sided pneumonia lasted 3 months after the delivery of the third child, caused acute liver failure. Liver transplantation was performed along the specific antibiotic therapy and IgM-enriched immunoglobulin treatment, which was successful and the mother is still alive.

\section{INFECTION AFTER TRANSPLANTATION}

The period after solid organ transplantation (SOT) can be divided into three parts from the infections point of view: the first month after transplantation, the first and the second sixth months. The "golden rule" is that the development of rejection indicates development of infection and the development of infection indicates development of rejection $(15,18)$. The timescale of the transplanted patients' infections offers help in differen- tial diagnosis and in planning the effective prophylaxis and empirical atibiotic therapy. It has a particular importance in the perioperative period, if there are other surgical procedures performed for other reasons (Figure 2).

\section{The $1^{\text {st }}$ month}

In case of infections during the first month the possibility of transition from the donor arises, but the infections generally correlate to the surgical procedure as well. The use of complex immunosuppression therapy begins immediately after surgery and requires time, therefore the early postoperative infections are mainly unrelated to the immunosuppressed state. The prevalence and type of infections match the not immunosuppressed patient's infections associated to surgical procedures. In this period pneumonia, urinary and biliary tract infection related to catheter, drain or intravenous devices can occur. In case of liver-transplanted patients, due to the surgical interventions of choledochotomy, choledochojejunostomy, the ascending type biliary infections are the most frequent, in cases of kidney-transplanted patients the urinary tract infections, in heart-transplanted patients mediastinitis or the aorta suture's fungal infection, in cases of lung-transplanted patients the bronchial anastomotic insufficiency or mediastinitis can develop (14). During the first weeks af-

\section{Conventional}

\section{Non-convencional}

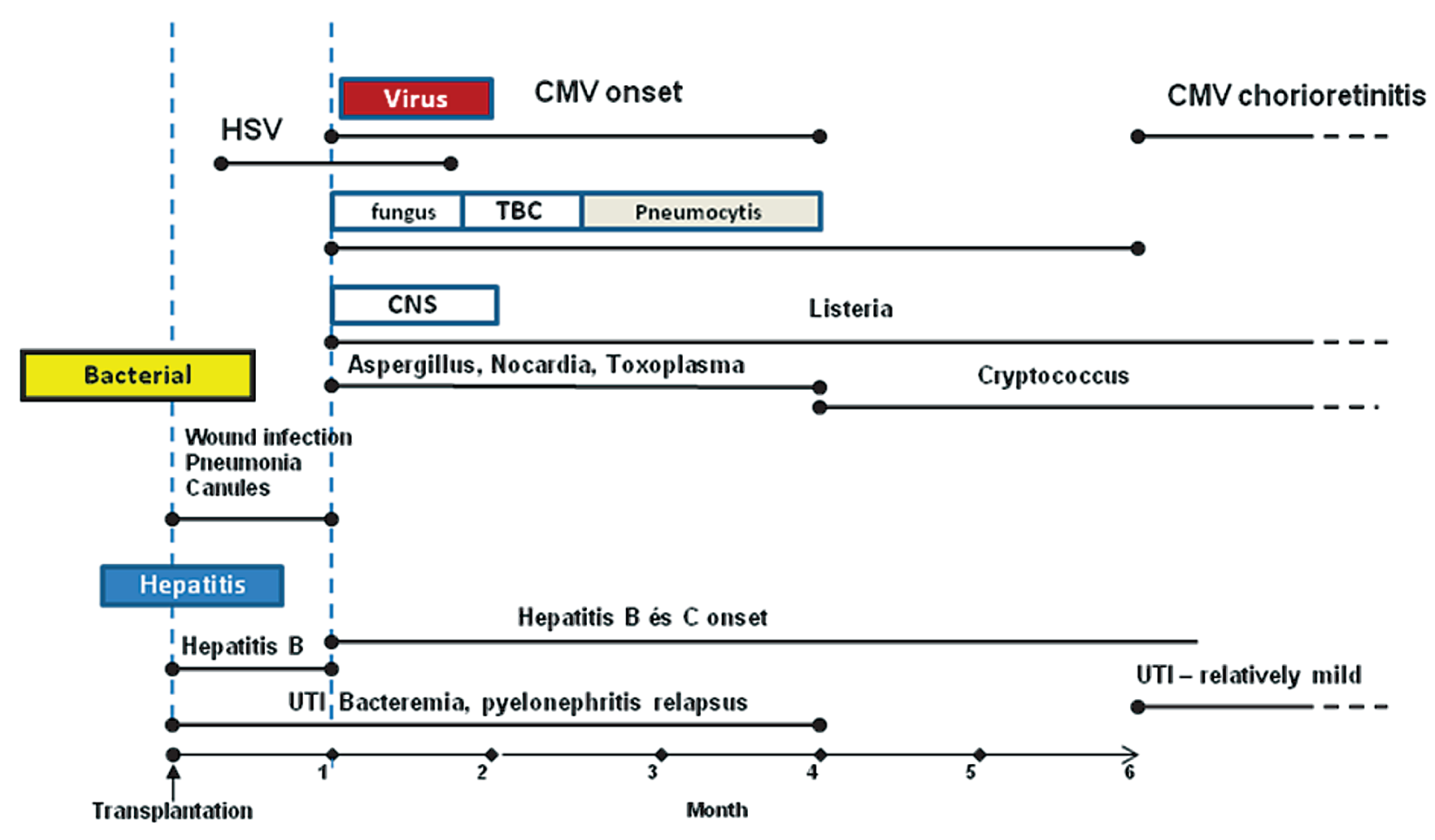

Figure 2. Occurrence of infections in timely order after transplantation

\footnotetext{
* CMV: cytomegalovirus; HSV: herpes simplex virus; CNS: central nervous system; TBC: tuberculosis; UTI: urinary tract infections; VZV: varicella zoster virus
} 
ter transplantation acute rejection can occur, of which treatment consists of usually administration of large dose steroids or anti-lymphocyte globulin. In this case the "over" immunosuppression is in favor of the appearance of the more severe opportunistic infections. The chronic lymph loss in the first few days caused by the damage of the lymphatic vessels during the operation could play a distinct role in the development of reduced immunoglobulin levels in the immediate postoperative period. These can cause immunosuppressed state by themselves and with addition of the drug-induced immunosuppression. Together they surely cause "over" immunosuppression, although separately they don't $(19,20)$ (Table 2).

Moreover, steroids but mostly the $\mathrm{T}$ and $\mathrm{B}$ lymphocyte proliferation inhibitor mycophenolate mofetil also contributes to the reduced IgM and IgG blood levels. So it is logical that during the treatment of infections based on surgical complication, polytransfusion or systematic disease in the early stages of septic shock parallel with the application of the sepsis guidelines IgM-enriched immunoglobulin therapy can also be used.

\section{From th $1^{\text {st }}$ to the $6^{\text {th }}$ months after transplantation}

The period between the first and sixth months after transplantation is when the nature of the transplanted patients' infections changes. The immunosuppression applied during transplantation inhibits the acquired immunity and is heterogenic and its complexity is given by the possibility of the combinations. We inhibit the antigen recognition with the help of steroids, the proliferation with the help of mycophenolate mofetil. The inhibition of the cytokines' production is the most commonly used option to prevent rejection and lately it is often combined with co-stimulation blockade. The effect of the combined immunosuppression is strongest between the first and sixth months after transplantation, therefore the classic opportunist infections are to be expected during this period: they develop in $33-68 \%$ of liver-transplanted patients, in $54 \%$ of lung transplanted patients, in $47 \%$ of kidney transplanted patients, in 35\% pancreas transplanted patients and in $21-30 \%$ of heart transplanted patients (Figure 1).

Out of the opportunistic viral infections the members of the herpes family have the highest significance, their main representative is the herpes type B cytomegalovirus infection (CMV). The CMV infection with a prolonged epidemic-like occurrence affects 10-50\% of the transplanted population. Its development depends on the donor's and the recipient's serological status, the characteristics of immunosuppression, the human leukocyte antigen (HLA) accordance and the
Table 2. The protein and immunoglobulin content of ascites after liver-transplantation (laboratory test results, own material). Depending on the daily loss, this lack/deficit can cause immunosuppression

\begin{tabular}{|c|c|c|}
\hline Parameter & $\begin{array}{c}\text { Value } \\
\text { measured from } \\
\text { ascites }(\mathbf{g} / \mathbf{L})\end{array}$ & $\begin{array}{c}\text { Serum normal } \\
\text { value } \mathbf{( g / L )}\end{array}$ \\
\hline Total protein & 44.3 & $60-85$ \\
\hline $\operatorname{IgA}$ & 0.83 & $0.7-4.0$ \\
\hline $\operatorname{IgG}$ & 2.84 & $7.0-16.0$ \\
\hline $\operatorname{IgM}$ & 0.41 & $0.4-2.3$ \\
\hline
\end{tabular}

type of the transplanted organ. It can appear as a mild or moderately severe "flu-like" syndrome, progressive colitis, hepatitis or gastritis, leukopenia, pneumonia or disseminated viral disease. Besides the direct effects of CMV the indirect effects are also very important. The CMV infection through its effects on the immune system raises the chance of opportunistic infections, e.g. in the presence of CMV infection the number of invasive fungal infections increases by 5-6-fold (21).

Among the other members of the human herpes virus family the HHV6 and HHV8 are the most important, which can cause for example pneumonia, encephalitis or myelosuppression. Their harmful effect as a cofactor is mostly set forth through immunomodulation, making the appearance of opportunist pathogens easier. One clear example for this is the role of Kaposi sarcoma-associated herpes virus (KSHV-HHV8) in the development of the transplantation-related late Kaposi sarcoma (21).

After transplantation in seronegative patients the varicella-zoster virus (VZV) can cause varicella, in seropositive patients it can cause herpes zoster. To prevent infection there is a blood test before the transplantation and depending on the result vaccination is advised. In bacterial or fungal superinfections immunoglobulin therapy should be considered (22).

Invasive fungal infections can originate from both endogen and exogen flora. The infection's progression is fast, therefore the initiation of the early empirical therapy is very important. Besides the adjuvant use of IgM-enriched immunoglobulins is an important and common sense part of the therapy. The aspecific clinical picture causes great difficulties in early diagnosis. The appearance of the non-albicans Candida, Aspergillus species and Fuzariums have become more and more common, which cause higher than average mortality among the immunosuppressed.

The incidence of Pneumocystis jiroveci is $3-11 \%$ without prophylactic treatment, it primarily causes pneumonia among the transplanted. It develops mainly in 


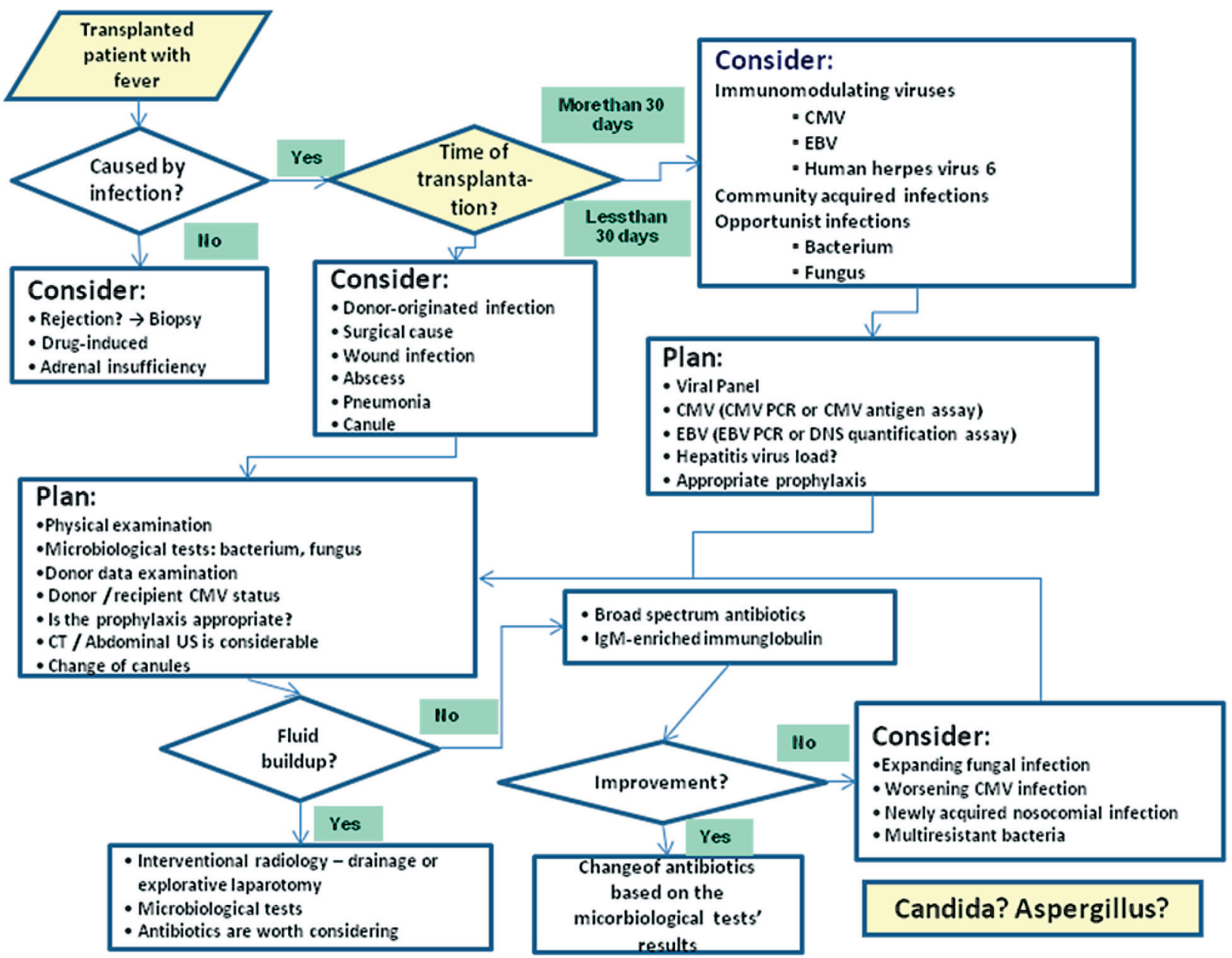

Figure 3. Supposed infections' diagnostics and treatment after the transplantation of parenchymal organ

*EBV: Epstein-Barr virus; CMV: cytomegalovirus; PCR: polymerase chain reaction

patients, who belong to the high risk group. The late diagnosis and late treatment causes high mortality here as well, but it can be easily prevented with prophylaxis (sulfonamid/ trimetoprim, in case of allergy pentamidin).

During the second period after transplantation (1-6 months) the opportunistic infections from the environment are also common (Nocardia, Listeria and Legionella infection), and unlike Mycobacterium, they don't cause infection through reactivation.

In severe sepsis and septic shock the use of early IgM-enriched immunoglobulins within the first 1-2 days is recommended. In patients suffering from severe sepsis, septic shock, the delay in the start of Pentaglobin ${ }^{\circledR}$ raises the mortality by $2.5 \%$ in every 24 hours $(23,24)$. This raises the mortality of transplanted patients with an even higher ratio.

\section{Six months after transplantation}

$5-10 \%$ of the SOT patients develop rejection or chronic graft insufficiency on an immunological basis. Among these patients the immunosuppressive therapy is more pronounced and the therapy against rejection is also more common. It causes deeper, longer immunosuppression with all of its consequences, among which the prolonged presence of opportunistic infections are important to note. $10 \%$ of patients with chronic rejection suffer from some kind of chronic, progressive infection as well. Aspecific infections, e.g. nocardiosis, aspergillosis may develop only from a significant environment-originated exposition. On the other hand viral infections are also common (hepatitis C, B virus; cytomegalovirus; Epstein-Barr virus; papillomavirus), which cause damage to the implanted organ and have a role in the development of tumors. In the period following the sixth month after transplantation $80 \%$ of SOT patients have good graft function and receive immunosuppressive treatment at the lowest possible dose. In this case the type of infections and their incidence usually equals to the non-transplanted population, and only differs in respiratory tract infections. The cause of this is the secondary hypogammaglobulinemia (IgG: 400-700 mg\%), which is caused by the mycophenolate mofetil (MMF) blood levels, which inhibit the $\mathrm{T}$ and B lymphocyte 
proliferation (25). In these cases the MMF can be changed to an alternative drug, and monthly IVIG therapy can be given during the follow-up. Along the humoral "over" immunosuppression the prevalence of the pulmonary infections is $2-3$-fold of the normal. Obviously if the same kind of patient arrives to the intensive care unit in the state of septic shock, the MMF therapy is to be stopped and a few days of IgM-enriched intravenous immunoglobulin therapy is recommended (26).

Although the course of bacterial infections look similar to that of in the non-immunosuppressed population, the course of certain viral infections can be more aggressive among the transplanted patients. In patients without prophylaxis or without definitive therapy (e.g. West Nile virus infection) the only treatment we can offer is the IgM-enriched immunoglobulin therapy as in addition to supportive therapy (27).

From a practical point of view it is important to be aware of the applied immunoglobulin product's characteristics: process of production, the method of conservation and most importantly, the pathogen specific antibody content. Regarding the patient, we have to know the plasma immunoglobulin content, and the answer to the three most important questions of the immunoglobulin therapy: when, how much, for how long. The details of a septic transplanted patient's immunosuppressed state must be known: its nature, its depth, its severity and for how long it has lasted, emphasizing the disorder of the cellular immunity. During the performance of microbiological tests we have to aim for the direct detection of the pathogen with histological, microbiological or with other antigen tests (punctions, bronchoalveolar lavage, biopsy). It is extremely important to start the combined broad spectrum antibiotic, antimycotic therapy immediately after the samples for microbiological tests are collected. With the use of laboratory tests in reasonable cases (MMF, steroids) the serum immunoglobulin levels and the levels of immunosuppressant must be determined and with its daily monitoring the doses must be reduced. The use of steroid monotherapy is possible if the graft function can be replaced with supportive therapy (e.g. in kidney-transplanted patients: hemodialysis). In case of a graft which stands for a vital organ the MMF is to be immediately stopped, other immunosuppression must be reduced to the border of rejection, and early use of IVIG or IgM-enriched immunoglobulin therapy must be started to strengthen immunity. Knowing the results of the microbiological tests (most likely the 3-5th day of therapy) antibiotics should be de-escalated, and the immunoglobulin therapy can be stopped $(28,29)$. The occurrence of potential side-effects, e.g. the kidney-failure, aberrant immunothrombosis, hemolysis, should be checked regularly (30) (Figure 2).

\section{CONCLUSION}

The use of intravenous immunoglobulins in patients undergoing SOT shows a growing tendency worldwide, and one of the main reasons is to aid the host response to infection. The general concept of organ support in the critically ill is valid in transplanted patients too, but the therapeutic window is smaller. Therefore, in cases of infections in transplanted, immunodeficient patients, the cornerstones of the treatment are reducing the degree of immunosuppression, starting empirical antimicrobial therapy as soon as possible and the use of IgM-enriched immunoglobulin therapy, besides the specific diagnostic and therapeutic interventions.
Abbreviations
CMV - Cytomegalovirus
CNS - Central nervous system
EBV - Epstein-Barr virus
HHV - Human herpes virus
HLA - Human leukocyte antigen
HSV - Herpes simplex virus
IVIG - Intravenous immunoglobulin
KSHV - Kaposi sarcoma-associated herpes virus
MMF - Mycophenolate mofetil
PCR - Polymerase chain reaction
SBP - Spontaneous bacterial peritonitis
SOT - Solid organ transplantation
TBC - Tuberculosis
UTI - Urinary tract infections
VZV - Varicella-zoster virus 


\title{
Sažetak
}

\section{ULOGA IgM-OBOGAĆENIH INTRAVENSKIH IMUNOGLOBULINA U TRANSPLANTACIJI}

\author{
Szabó Judit, Smudla Anikó, Fazakas János \\ Semmelweis University, Department of Transplantation and Surgery, Hungary
}

Nakon transplantacije organa, gama globulini i IgM-obogaćeni intravenski imunoglubulini su najčešće korišćeni u terapiji septičkog šoka kao rana imuno podrška. Ako je izvadjeni organ inficiran, transplantacija, kao operacija od vitalnog značaja, može biti izvedena ukoliko nema sistemske upale i pacijent primi IgM obogaćene imunoglobuline kao profilaksu tokom hirurškog zahvata. Period nakon transplatancije organa može biti podeljen na tri perioda $\mathrm{u}$ odnosu na infekciju: prvi mesec nakon transplantacije, prvih šest meseci nakon transplantacije i sledećih šest meseci. Infekcije u prvih mesec dana su u osnovi povezane sa hirurškom procedurom. Zbog imuno-supresivne terapije, oprtunističke i gljivične infekcije su češće tokom prvih šest meseci. Nakon ovog perioda, učestalost i vrste infekcija su slične onim kod populacije koja nije imala transplantaciju, osim plućnih infekcija,

\section{REFERENCES}

1. Eibl MM. History of immunoglobulin replacement. Immunol Allergy Clin N Am. 2008; 28(4): 737-64.

2. Dellinger RP, Levy MM, Rhodes A, et al. Surviving sepsis campaign: international guidelines for management of severe sepsis and septic shock: 2012. Crit Care Med. 2013; 41(2): 580-637.

3. Soares MO, Welton NJ, Harrison DA, et al. An evaluation of the feasibility, cost and value of information of a multicentre randomised controlled trial of intravenous immunoglobulin for sepsis (severe sepsis and septic shock): incorporating a systematic review, meta-analysis and value of information analysis. Health Technol Assess. 2012; 16(7): 1-186.

4. Toth I, Mikor A, Leiner T, et al. Effects of IgM-enriched immunoglobulin therapy in septic-shock-induced multiple organ failure: pilot study. J Anesth. 2013; 27(4): 618-22.

5. Alejandria MM, Lansang MA, Dans LF, Mantaring JB. Intravenous immunoglobulin for treating sepsis, severe sepsis and septic shock. Cochrane Database Syst. 2013; 16(9): CD001090.

6. Monserrat J, de Pablo R, Diaz-Martin D, et al. Early alterations of $\mathrm{B}$ cells in patients with septic shock. Crit Care. 2013; 17(3): R105.

7. Moreira RK, Revetta F, Koehler E, Washington MK.. Diagnostic utility of IgG and IgM immunohistochemistry in autoimmune liver disease. World J Gastroenterol. 2010; 16(4): 453-7.

8. Tamayo E, Fernández A, Almansa R, et al. Beneficial role of endogenous immunoglobulin subclasses and isotypes in septic shock. J Crit Care. 2012; 27(6): 616-22.

9. Ammerlaan HSM, Harbarth S, Buiting AG, et al. Secular trends in nosocomial bloodstream infections: Antibiotic-resistant bacteria increase the total burden of infection. Clin Infect Dis. 2013; 56(6): 798-805. koje su dva do tri puta češće. Objašnjenje je sekundarna hipogamaglobulinemija (niži nivo u krvi IgM i IgG antitela) koja je prouzrokovana steriodima, ali najčešće mikofenolat mofetilom usled inhibicije proliferacije $\mathrm{T}$ i B limfocita. Septički šok razvija se sa kontinuiranim padom nivoa IgM antitela. Usled ovih okolnosti dodatna intravenska imunoglobulinska terapija sa IgM antitelima može biti od životne važnosti. Osim toga, IgM obogaćeni imunoglobini mogu se koristiti kod virusnih infekcija bez profilakse i/ili bez etiološke terapije, kao što je slučaj kod infekcija izazvanih virusom Zapadnog Nila. Kako je aktuelan porast rezistencije na antibiotike, primena imunoterapije, uključujući i imunoglobuline, može biti osnova u lečenju septičkog šoka.

Ključne reci: imunoglobulini, IgM, septički šok, transplantacija.

10. Berry JD, Gaudet RG. Antibodies in infectious diseases: polyclonals, monoclonals and niche biotechnology. New Biotechnology. 2011; 28(5): 489-501.

11. Mark H Wilcox. Updated guidance on the management and treatment of Clostridium difficile infection. London: Public Health England gateway number; 2013.

12. Glotz D, Antoine C, Julia P, et al. Intravenous immunoglobulins and transplantation for patients with anti-HLA antibodies. Transpl Int. 2004; 17(1): 1-8.

13. Ameratunga R, Woon ST, Gillis D, Koopmans W, Steele R. New diagnostic criteria for common variable immune deficiency (CVID), which may assist with decisions to treat with intravenous or subcutaneous immunoglobulin. Clin Exp Immunol. 2013; 174(2): 203-11.

14. Perner F, Petrányi Gy, editors. Szervátültetés. $1^{\text {st }}$ ed. Budapest: Medicina Könyvkiadó Zrt; 2013.

15. Tassonyi E, Fülesdi B, Molnár Cs. Perioperatív betegellátás. $1^{\text {st }}$ ed. Budapest: Medicina Könyvkiadó Zrt; 2009.

16. Frances R, Benlloch S, Zapater P, et al. A sequential study of serum bacterial DNA in patients with advanced cirrhosis and ascites. Hepatology. 2004; 39(2): 484-91.

17. Pandey CK, Singh N, Kumar V, Agarwal A, Singh PK.Typhoid, hepatitis E, or typhoid and hepatitis E: the cause of fulminant hepatic failure - a diagnostic dilemma. Crit Care Med. 2002; 30(2): 376-8.

18. Bowden R, Ljungman P, Snydman DR, editors. Transplant Infections. 3rd ed. Philadelphia: Lippincott Williams \& Wilkins; 2010.

19. Hlava N, Niemann CU, Gropper MA, Melcher ML. Postoperative infectious complications of abdominal solid organ transplantation. J Intensive Care Med. 2009; 24(1): 3-17.

20. Jordan SC, Toyoda M, Kahwaji J, Vo AA. Clinical aspects of intravenous immunoglobulin use in solid organ transplant recipients. Am J Transplant. 2011; 11(2): 196-202. 
21. Mandell G, Bennett JE, Dolin R. Infection in special host. In: Mandell G, Bennett JE, Dolin R, editors. Mandell, Douglas and Bennett's Principles and Practice of Infectious. 6th ed. Philadelphia: Elsevier; 2005. p. 3421-524.

22. Ludwig E, Szalka A, editors. Infektológia. 1' ed. Budapest: Medicina Könyvkiadó Zrt; 2009.

23. Berlot G, Vassallo MC, Busetto N, et al. Relationship between the timing of administration of IgM and IgA enriched immunoglobulins in patients with severe sepsis and septic shock and outcome: A retrospective analysis. J Crit Care. 2012; 27(2): 167-71.

24. Shankar-Hari M, Spencer J, Sewell WA, Rowan KM, Singer M. Bench-to-bedside review: Immunoglobulin therapy for sepsis - biological plausibility from a critical care perspective. Crit Care. 2012; 16(2): 206.

25. Florescu DF, Kalil AC, Qiu F, Schmidt CM, Sandkovsky U.. What is the impact of hypogammaglobulinemia on the rate of infections and survival in solid organ transplantation? A meta-analysis. Am J Transplant. 2013; 13(10): 2601-10.

26. Giamarellos-Bourboulis EJ, Apostolidou E, Lada M, et al. Kinetics of circulating immunoglobulin $\mathrm{M}$ in sepsis: relationship with final outcome. Crit Care. 2013; 17(5): R247.

27. Smudla A, Gergely L, Varga M, et al. West Nile virus encephalitis in kidney transplanted patient, first case in Hungary: a case report. IMAS. 2011; 3(2): 80-3.

28. Hartung HP, Mouthon L, Ahmed R, Jordan S, Laupland KB, Jolles S. Clinical applications of intravenous immunoglobulins (IVIg) - beyond immunodeficiencies and neurology. Clin Exp Immunol. 2009; 158 Suppl 1:S23-3.

29. Rodríguez A, Rello J, Neira J, et al. Effects of high-dose of intravenous immunoglobulin and antibiotics on survival for severe sepsis undergoing surgery. Shock. 2005; 23(4): 298-304.

30. Stiehm R. Adverse Effects of Human Immunoglobulin Therapy. Transfusion Medicine Reviews. 2013; 27(3): 171-8.

\section{Correspondence to/Autor za korespondenciju}

János Fazakas

Phone: +36208258620; Fax: +3613170964

Baross utca 23.

Budapest, H-1082, Hungary 